\title{
Computational algorithm for the verification of reinforced concrete sections in fire situation
}

\section{Algoritmo computacional para verificação de seções de concreto armado em situação de incêndio}
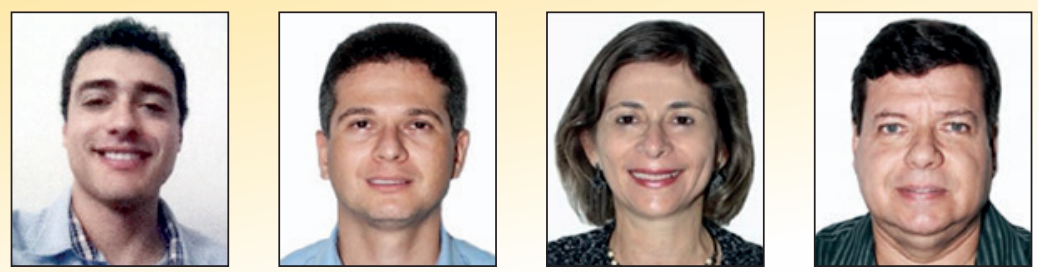

E. P. G. PADRE a elderpadre@hotmail.com https://orcid.org/0000-0001-9650-7284

J. C. L. RIBEIRO a
jcarlos.ribeiro@ufv.br
$\begin{array}{r}\text { https://orcid.org/0000-0003-4069-7001 } \\ \text { R. C. S. S. ALVARENGA a } \\ \text { in memorian } \\ \text { R. C. SILVA a } \\ \text { recsilva@ufv.br }\end{array}$
https://orcid.org/0000-0003-4908-9555

\begin{abstract}
Reinforced concrete structures may have reduced strength due to the degradation of their mechanical properties by temperature. This can increase the risk of structural collapses. Thus, the structural design should consider its behavior at room temperature and in fire situation (ABNT NBR 14432:2001). This study presents the development of an algorithm to verify the strength of any reinforced concrete sections subjected to unsymmetrical bending at room temperature and in fire situation. For this purpose, a stress integration algorithm was implemented from the strain profile of the section according to ABNT NBR 15200:2012, linked to a finite element mesh generator and a thermal analysis algorithm. For validation of the developed program, called Pisafo, the results obtained were compared with those in the technical literature: obtained in experiments (with differences of up to $28.5 \%$ ) and with recognized software solutions (with differences of up to $-14.8 \%$ ). The largest variations in relation to the experiments can be attributed to the differences between the thermal properties of the concrete in the experiments with those prescribed in the technical standards used by the program and the non-consideration of spalling in the computational analysis.
\end{abstract}

Keywords: reinforced concrete, fire, design, unsymmetrical bending, computational algorithm.

\section{Resumo}

As estruturas de concreto armado podem ter sua capacidade resistente reduzida devido à degradação de suas propriedades mecânicas com a temperatura, aumentando o risco de colapsos estruturais. Assim, o dimensionamento de uma estrutura deve considerar seu comportamento em temperatura ambiente e em situação de incêndio (ABNT NBR 14432:2001). Neste trabalho, apresenta-se o desenvolvimento de um algoritmo para verificação da resistência de seções quaisquer de concreto armado à flexão composta oblíqua em temperatura ambiente e em incêndio. Para isso, implementou-se um algoritmo integrador de tensões a partir do perfil de deformações da seção segundo a ABNT NBR 15200:2012, vinculado com um gerador de malhas de elementos finitos e com um algoritmo de análise térmica. Na validação do programa desenvolvido, denominado Pisafo, compararam-se os resultados obtidos com os apresentados na literatura: obtidos em experimentos, com diferenças de até $28,5 \%$, e com programas consagrados, com diferenças de até $-14,8 \%$. As maiores variações em relação aos experimentos podem ser atribuídas às diferenças entre as propriedades térmicas do concreto nos experimentos com as prescritas em normas utilizadas no programa e à não consideração do spalling na análise computacional.

Palavras-chave: concreto armado, incêndio, verificação, flexão composta oblíqua, algoritmo computacional.

\footnotetext{
Federal University of Viçosa, Department of Civil Engineering, Viçosa, MG, Brazil.
}

Received: 08 Oct $2017 \cdot$ Accepted: 05 Feb 2018 • Available Online: 08 Aug 2019

This is an open-access article distributed under the terms of the Creative Commons Attribution License 


\section{Introduction}

According to Brushlinsky et al. [1], in 2014, in 23 countries surveyed, there were recorded a total of 819,265 fires in buildings, involving thousands of people injured and killed, as well as a financial loss of millions of dollars caused by the fires.

To avoid further material losses and especially lives, research in the field of fire has intensified more and more. Experiments with the goal of investigating the behavior of reinforced concrete elements subjected to high temperatures [2, 3, 4, 5], researches for the analysis of thermal and thermomechanical problems of structures $[6,7,8,9]$, studies that have investigated and provided simplified $[10,11,12,13,14]$ and alternative $[15,16,17]$ methods for design and verification of reinforced concrete elements have been performed in recent times.

Studies on design up to that time were limited to analyzing rectangular sections of reinforced concrete in fire situation, comprising only normal composite bending. Therefore, there is a deficiency in the general treatment of composite bending (normal and unsymmetrical) for its application in other sections, such as $T, L$ and circular sections, widely used today as columns in tall buildings.

In order to evaluate a structure in fire situation, it is necessary first to understand the fire phases, compartment geometry, type of combustible material, type of masonry coating and degree of ventilation, according to Silva [18]. Only then it is possible to select a fire curve $[19,20,21,22]$ suitable for the good simulation of the reinforced concrete structure.

The main advantage of reinforced concrete is that many buildings with this type of structure that suffered serious fires could be restored and put back into use [23], such as the Santos Dumont airport building in Rio de Janeiro - Brazil [24]. Due to a slow heat transfer, the internal region of the cross-sections of reinforced concrete does not reach the high temperatures of the faces exposed to fire, remaining with lower temperatures and, therefore, greater mechanical strength [25]. This characteristic provides a good degree of rehabilitation to concrete structures.

In relation to the decay of mechanical properties of the concrete with the temperature, this can be attributed to the physical-chemical changes in the cement paste and in the aggregates, and to the difference in the thermal deformations between these [26]. In this way, the greater problems caused in the reinforced concrete structure occur at temperatures in the range of $500{ }^{\circ} \mathrm{C}$ to $600{ }^{\circ} \mathrm{C}$ [27]. It is within this range that the steel of the reinforcement rapidly loses its tensile strength.

An important phenomenon that occurs in structural elements of reinforced concrete in fire situation is the spalling, which causes loss of the resistant area due to the concrete disintegration [28]. Spalling can be manifested as pop-out, from an aggregate, due to the differential thermal deformations between the aggregate and the concrete matrix (Figure 1.a); as sloughing as shown in Figure 1.b; or as explosive spalling, Figure 1.c.

There are several reasons that influence the occurrence of spalling: moisture content, porosity and permeability of concrete, stress conditions, type of aggregate used in concrete, section of the element, concrete cover used and rate of heating [29, 30]. Each factor mentioned has its peculiarities and can act increasing or decreasing the probability of occurrence of this phenomenon in the concrete. Some researchers have already observed that the moisture content has a great influence on the internal temperature of the concrete elements, besides directly interfering with the pore-pressure developed during the heating process [31]. Deeny et al. [32] emphasize the importance of the implementing fully coupled hygrothermo-mechanical models for an accurate evaluation of spalling, but highlight the great variability that the numerical results can present in relation to experimental data.

Thus, by knowing the effects of fire, it is necessary to consider the changes in the thermal and mechanical properties of concrete and steel due to the temperature increase in these materials. The thermal properties required for thermal analysis of the materials composing the reinforced concrete are the specific mass, influenced by the water loss of the concrete matrix and by the volume variation due to material expansion, specific heat and thermal conductivity [29]. With respect to the main mechanical properties of the materials composing the reinforced concrete, it can be mentioned the modulus of elasticity, the tensile and compressive strength and the stress-strain relationships [29].

In this context, there are no studies on the development of an algorithm for the verification of the strength of any sections of reinforced concrete when subjected to unsymmetrical bending. Thus, this study aimed to present a computational algorithm capable of

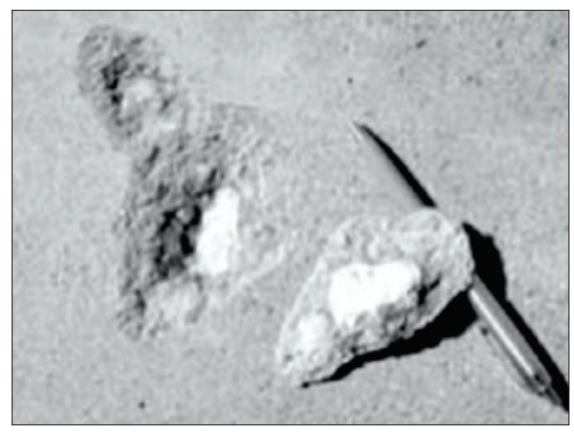

(a) Pop-out

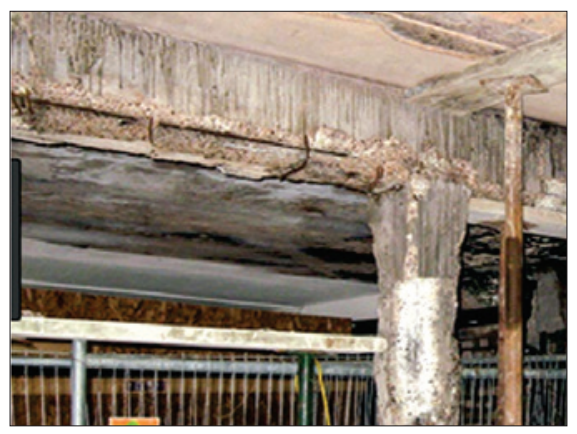

(b) Sloughing



(c) Explosive spalling

Figure 1

Types of spalling in concrete

Source: www.google.com 
numerically simulating, in $2 \mathrm{D}$, the temperature distribution in reinforced concrete sections in fire situation, following any fire curve (temperature $\times$ time), and to verify its resistance subjected to unsymmetrical bending. In addition, with this algorithm it is possible to construct the $M_{y} \times M_{x}, M_{x} \times N$ and $M_{y} \times N$ interaction diagrams of concrete cross-sections for various fire exposure times.

Importantly, the algorithm shown in this research encloses an alternative method of design, not considering the influence of spalling and thermal deformations of the materials on the strength capacity of the elements evaluated.

\section{Material and methods}

The computational algorithm developed in this study, called Pisafo, corresponds to the mechanical analysis, a stress integration from the cross-section strain profile, directly coupled to a finite element mesh generator and to a thermal analysis algorithm. Each of these modules is described in the following items.

\subsection{Mesh generation}

To generate the finite element mesh, Pisafo uses the algorithm of the EasyMesh mesh generator [33], with its converted code from C++ (its default language) to Delphi, by Bitencourt [34].

EasyMesh is a freeware two-dimensional mesh generator for three-node linear triangular elements developed at MIT. It allows to generate an unstructured mesh with or without holes, and it is also possible to perform a localized refinement or coarsening of the mesh.

EasyMesh uses the Delaunay triangulation, the Laplace smoothing, and has a relaxation method to avoid creating nodes surrounded by more than 7 and less than 5 elements.

\subsection{Thermal analysis}

For thermal analysis, Pisafo uses the thermal analysis algorithm of Thersys, also developed in Delphi by Ribeiro [7]. This algorithm performs transient and nonlinear thermal analysis for two-dimensional and three-dimensional elements of any geometry, considering several fire curves and the thermal properties of the materials. The temperature of the structural elements is determined by the differential heat transfer formulation adapted to the Finite Element Method, based on a fire curve and dependent on the boundary conditions.

\subsubsection{Mechanisms of heat transfer}

For the simulation of a fire, there is a combined action of the three mechanisms of heat transfer: conduction (in the domain), convection and radiation (in the boundary).

\section{a) Conduction}

In conduction, energy is propagated through molecular agitation within a body or environment (solid, liquid or gaseous), or between different bodies in physical contact. The heat transfer by conduction is given by the Fourier law according to Equation (1):

$\lambda \nabla^{2} \theta+Q=\rho c \frac{\partial \theta}{\partial t}$ where $\lambda$ is the thermal conductivity of the material $\left(\mathrm{W} /\left(\mathrm{m}^{\circ} \mathrm{C}\right)\right), \nabla$ is the differential operator (gradient), $\theta$ is the material temperature $\left({ }^{\circ} \mathrm{C}\right), Q$ is the heat flux generated inside the material $\left(\mathrm{W} / \mathrm{m}^{3}\right), \rho$ is the specific mass of the material $\left(\mathrm{kg} / \mathrm{m}^{3}\right), c$ is the specific heat of the material $\left(\mathrm{J} /\left(\mathrm{kg}^{\circ} \mathrm{C}\right)\right), t$ is the time $(\mathrm{s})$ and $\partial \theta / \partial t$ is the temperature gradient in time.

\section{b) Convection}

Convection is a mechanism of heat transfer through the movement of a fluid or between it and solid surfaces (where the fluid corresponds to the heated gases and the solid is the structural element). When convection currents form due to the difference in density (and temperature) between masses of gases, natural convection occurs. If these currents are caused by external reasons, forced convection is considered.

The convection heat flux is determined by Newton's law of cooling, according to Equation (2):

$q=\alpha_{c}\left(\theta_{s}-\theta_{f}\right)$

where $q$ is the convective heat flux emitted by the surface per unit area $\left(\mathrm{W} / \mathrm{m}^{2}\right), \alpha_{c}$ is the coefficient of heat transmission by convection $\left(\mathrm{W} /\left(\mathrm{m}^{2}{ }^{\circ} \mathrm{C}\right)\right), \theta_{s}$ is the surface temperature of the solid $\left({ }^{\circ} \mathrm{C}\right)$ and $\theta_{f}$ is the average temperature of the fluid $\left({ }^{\circ} \mathrm{C}\right)$.

\section{c) Radiation}

The transfer of heat by radiation occurs through the propagation of electromagnetic waves due to the diffusion of the flames. As these waves can propagate in a vacuum, unlike conduction and convection, no contact between bodies is required. In addition, heat transmission through radiation has its maximum efficiency in the vacuum [8]. The maximum flow of radiant heat that can be emitted by the surface is calculated by Equation (3) developed by an experiment carried out by Josef Stefan in 1879 and, analytically, by Ludwig Boltzmann in 1884, called the StefanBoltzmann law:

$q=\varepsilon_{\text {res }} \sigma\left(\theta_{s}^{4}-\theta_{f}^{4}\right)$

where $q$ is the net heat flux emitted by radiation $\left(\mathrm{W} / \mathrm{m}^{2}\right), \varepsilon_{\text {res }}$ is the resultant emissivity of the heated surface, $\sigma$ is the StefanBoltzmann constant of proportionality equal to $5.6697 \times 10^{-8}(\mathrm{~W} /$ $\left.\left(m^{2} K^{4}\right)\right), \theta_{s}$ is the absolute surface temperature of the solid (Kelvin) and $\theta_{f}$ is the average absolute temperature of the fluid (Kelvin).

Thersys allows several boundary conditions, of which Pisafo inherits basically two types, combining convection and radiation, according to Equation (4):

- surfaces with cooling, where $\theta_{f}$ is the room temperature;

- fire surfaces, where $\theta_{f}$ is the temperature of hot gases.

$q=-\lambda \frac{\partial \theta}{\partial n}=\alpha_{c}\left(\theta_{s}-\theta_{f}\right)+\varepsilon_{r e s} \sigma\left(\theta_{s}^{4}-\theta_{f}^{4}\right)=\alpha\left(\theta_{s}-\theta_{f}\right)$ in $\Gamma_{q}$

where $\partial \theta / \partial n$ is the surface temperature gradient and $\alpha$ is the convective-radiative coefficient.

In addition to these cases, the boundary condition in which the surface is isolated (adiabatic) is also possible. In this way, there is no heat transfer between the structure and the gases.

\subsubsection{Structure of Thersys}

The program Thersys was elaborated using the concept "object oriented" with the aim of facilitating maintenance and additions in 


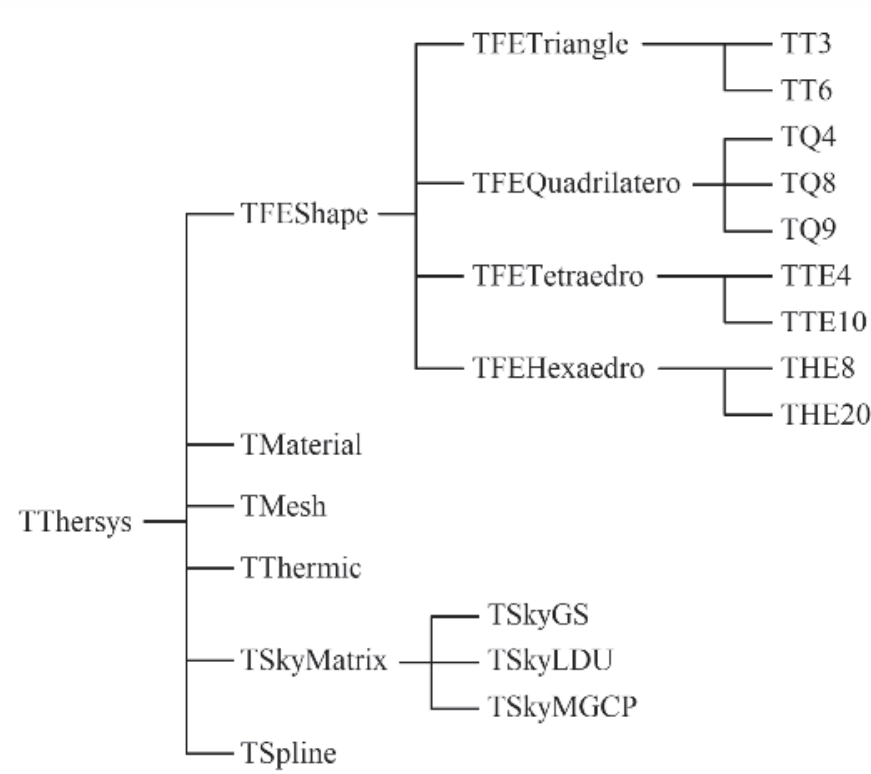

\section{Figure 2}

Structure of the program Thersys in classes [7]

the code [7]. The structure of the program can be seen in Figure 2. The program Pisafo inherits from Thersys the classes TFEShape, TThermic and TSKYMatrix, that allow to perform the thermal analysis. The TSpline class acts as a secondary class to manage interpolation of user-supplied data in the form of tables.

The class TFEShape manages the class TFETriangle that contains the Gaussian quadrature tables, calculates the Jacobian and the Cartesian derivatives. It also has the form functions and the local derivatives (class TT3) for the finite element generated by the EasyMesh algorithm.

The class TSkyMatrix solves the system of equations. It manages the stiffness matrix and makes the call available to the TSkyLDU (Cholesky factorization) solution algorithm.

The class TThermic manages the data and the coefficients of the thermal problem, calculates all the thermal matrices, vectors of nodal flows and performs thermal analysis using an iterative and incremental algorithm [7].

\subsection{Mechanical analysis}

The stress/strain profile integration algorithm for obtaining the interaction diagrams of concrete cross-sections comprises the following steps:

\section{a) center of gravity of the cross section.}

The total area of the cross section and the static moments of area around the $x$ and $y$ axes can be obtained by Gaussian quadrature according to Equations (5), (6) and (7), respectively. The coordinates of the center of gravity are given by Equations (8) and (9):

$A_{t}=\sum_{e=1}^{\text {nelem }} \sum_{p=1}^{n p g}|J| w$

$Q_{x}=\sum_{e=1}^{n e l e m} \sum_{p=1}^{n p g} y_{p}|J| w$
$Q_{y}=\sum_{e=1}^{n e l e m} \sum_{p=1}^{n p g} x_{p}|J| w$

$x_{g}=Q_{y} / A_{t}$

$y_{g}=Q_{x} / A_{t}$

where $A_{t}$ is the total area of the section, nelem is the number of elements in the mesh, npg is the number of Gauss points in the element, $|J|$ is the determinant of the Jacobian matrix at the Gauss point, $w$ is the weight of the Gauss point in the quadrature, $Q_{x}$ is the static moment of area around the $x$-axis, $y_{p}$ is the coordinate $y$ of the Gauss point, $Q_{y}$ is the static moment of area around the $y$-axis, $x_{p}$ is the coordinate $x$ of the Gauss point, $x_{g}$ and $y_{g}$ are the coordinates of the center of gravity.

b) distances for the calculation of the strain profile

The distances for calculating the strain profile are illustrated in Figure 3. Given the angle ( $\beta$ ) that the neutral line makes with the $x$-axis, it is necessary to identify the highly compressed edge of the concrete section farthest from the center of gravity $\left(x_{c c}\right)$, the tensioned edge of the concrete section farthest from the center of gravity $\left(x_{c t}\right)$ and the tensile reinforcement bar farthest from the center of gravity $\left(x_{t t}\right)$.

In order to calculate these distances, one must first obtain the coordinates $\left(x_{\beta}\right.$ and $\left.y_{\beta}\right)$ of the unit vector perpendicular to the neutral line $(N L)$, according to Equations (10) and (11):

$x_{\beta}=\cos \left(\beta+90^{\circ}\right)$

$y_{\beta}=\operatorname{sen}\left(\beta+90^{\circ}\right)$

The calculation of distances is done by projecting the position vector (with origin at the center of gravity) of each edge of the crosssection and the reinforcements in the direction of the unit vector perpendicular to the neutral line, according to Equation (12):

$d_{i}=\left(x_{i}-x_{g}\right) x_{\beta}+\left(y_{i}-y_{g}\right) y_{\beta}$

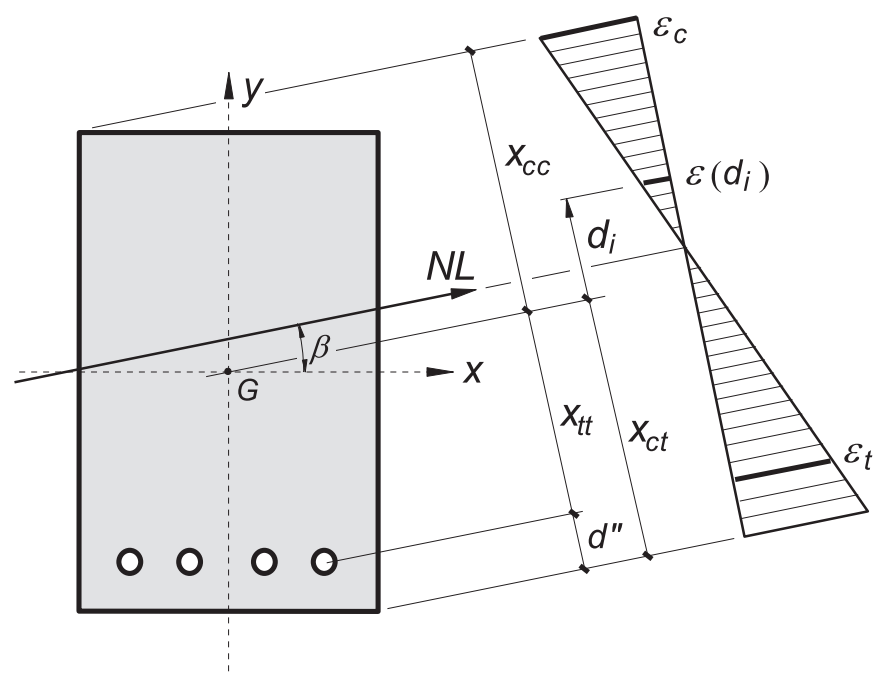

Figure 3

Distances in a section considering the neutral line at an $\beta$ angle to the $x$-axis 


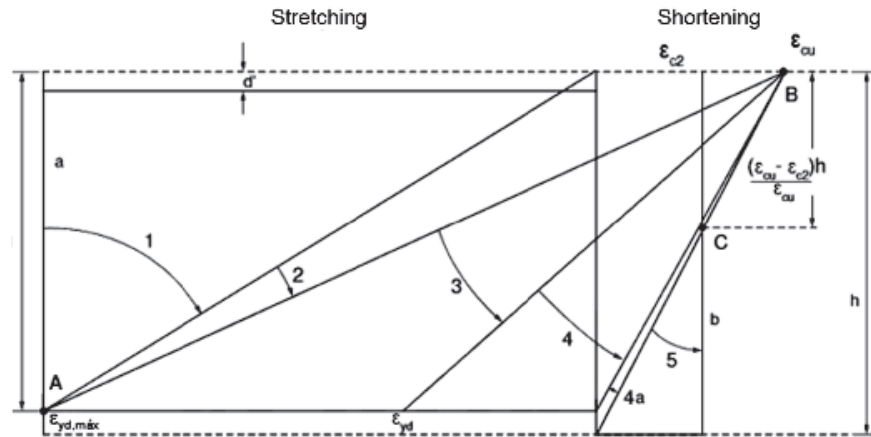

Figure 4

Domains of strain at the ultimate limit-state according to ABNT NBR 61 18:2014 [35]

where $x_{i}$ and $y_{i}$ are the coordinates of the point under analysis and $d_{i}$ is the distance from that point to the center of gravity (G), measured perpendicular to the neutral line.

c) strain limits for concrete $\left(\varepsilon_{c}\right)$ and reinforcement $\left(\varepsilon_{t}\right)$

After determining the maximum steel strain $\left(\varepsilon_{y d, m a x}\right)$ according to the steel type and its temperature [35, 36], the strains $\varepsilon_{c}$ and $\varepsilon_{t}$, shown in Figure 3, are calculated. These strains are obtained in function of the variable $\delta$, from the definition of the strain domains at the ultimate limit state (Figure 4) and their fractions, according to Equation (13).

$\delta=\left\{\begin{array}{ccc}0 & \rightarrow & \text { line a } \\ 0<\delta \leq 10 & \rightarrow & \text { domain } 1 \\ 10<\delta \leq 20 & \rightarrow & \text { domain } 2 \\ 20<\delta \leq 30 & \rightarrow & \text { domain } 3 \\ 30<\delta \leq 40 & \rightarrow & \text { domain } 4 \\ 40<\delta \leq 50 & \rightarrow & \text { domain 4a } \\ 50<\delta<60 & \rightarrow & \text { domain } 5 \\ 60 & \rightarrow & \text { line b }\end{array}\right.$

d) strain at Gauss points in the finite element mesh

The strain at a Gauss point of the mesh can be obtained by the Strain Compatibility Method, considering a similarity of triangles based on the strains of the regions defined by the coordinates $x_{c c}$ $\left(\varepsilon_{c}\right)$ and $x_{t t}\left(\varepsilon_{t}\right)$, according to Equation (14) and Figure 3:

$\varepsilon\left(d_{i}\right)=\frac{\varepsilon_{c}\left(x_{t t}+d_{i}\right)}{x_{c c}+x_{t t}}+\frac{\varepsilon_{t}\left(x_{c c}-d_{i}\right)}{x_{c c}+x_{t t}}$

where $d_{i}$ is the distance from the Gauss point to the center of gravity of the section, measured perpendicular to the neutral line, and obtained as a function of its coordinates $\left(x_{i}, y_{i}\right)$ from Equation (12). e) stress at Gauss points

The calculation of the stress at each Gauss point of the mesh from

\section{Table 1}

Parameters for the parabola-rectangle diagram of ABNT NBR 61 18:2014 [35] according to the concrete class

\begin{tabular}{ccc}
\hline Parameters & $<$ C50 & C50 to $\mathbf{C 9 0}$ \\
\hline$\varepsilon_{\mathrm{c} 2}(\%)$ & 2.0 & $2.0+0.085\left(\mathrm{f}_{\mathrm{ck}}-50\right)^{0.53}$ \\
$\varepsilon_{\mathrm{cu}}(\%)$ & 3.5 & $2.6+35\left(\left(90-\mathrm{f}_{\mathrm{ck}}\right) / 100\right)^{4}$ \\
$\mathrm{n}$ & 2.0 & $1.4+23.4\left(\left(90-\mathrm{f}_{\mathrm{ck}}\right) / 100\right)^{4}$ \\
\hline
\end{tabular}

the strain profile is performed considering the parabola-rectangle diagram presented by ABNT NBR 6118:2014 [35] or the diagram indicated by ABNT NBR 15200:2012 [36], and for the reinforcement, the simplified diagram presented by Moreira et al. [17] or the diagram indicated by ABNT NBR 15200:2012 [36].

\section{- concrete}

The stress-strain diagram of the concrete at high temperatures is obtained by the third-order Popovics equation indicated by ABNT NBR 15200:2012 [36] and by EN 1992-1-2:2004 [29], according to Equation (15).

$\sigma_{c, \theta}=f_{c k} k_{c, \theta} \frac{3\left(\frac{\varepsilon_{c, \theta}}{\varepsilon_{c 1, \theta}}\right)}{2+\left(\frac{\varepsilon_{c, \theta}}{\varepsilon_{c 1, \theta}}\right)^{3}}$

where $\sigma_{c, \theta}$ is the compressive stress value of the concrete at high temperature, $f_{c k}$ is the characteristic strength of concrete at room temperature, $k_{c, \theta}$ is the concrete strength reduction coefficient for high temperatures [36], $\varepsilon_{c, \theta}$ is the specific linear strain of concrete at high temperature, Equation (14), and $\varepsilon_{c 1, \theta}$ is the specific linear strain corresponding to the maximum compressive strength of the concrete at high temperature [36].

Alternatively to the diagram proposed by ABNT NBR 15200:2012 [36], according to previous studies conducted by Albuquerque et al. [15] and Moreira et al. [17] with satisfactory results, it can be used the parabola-rectangle diagram of ABNT NBR 6118:2014 [35], considering the strength of concrete adapted to high temperatures, as follows:

$\sigma_{c, \theta}=\left\{\begin{array}{cc}f_{c k} k_{c, \theta}\left[1-\left(1-\frac{\varepsilon_{c}}{\varepsilon_{c 2}}\right)^{n}\right], & \text { for } 0 \leq \varepsilon_{c}<\varepsilon_{c 2} \\ f_{c k} k_{c, \theta}, & \text { for } \varepsilon_{c 2} \leq \varepsilon_{c} \leq \varepsilon_{c u}\end{array}\right.$

in which $\varepsilon_{c 2}$ is the specific compressive strain of the concrete at reaching the maximum strength, and $\varepsilon_{c u}$ is the ultimate compressive strain (rupture), both indicated in Table 1.

- reinforcement (steel)

The stress-strain diagrams of the passive reinforcement bars at high temperatures can be elaborated from the equations indicated by ABNT NBR 15200:2012 [36].

Alternatively, it can be used the simplified diagram proposed in ABNT NBR 6118:2014 [35], with the expressions also adapted for high temperatures. Although this diagram is valid only for the temperature range between $-20^{\circ} \mathrm{C}$ and $150^{\circ} \mathrm{C}$, in previous studies by Soares [12], Castro [37] and Moreira et al. [17] this diagram was used to calculate structures in fire situation and the results were satisfactory.

For this diagram, the steel yield strain at high temperatures is given by:

$\varepsilon_{y d, \theta}=\frac{f_{y} k_{s, \theta}}{E_{s} k_{E s, \theta}}$

and the stress in the reinforcement bars at high temperatures can be obtained by:

$\sigma_{s, \theta}=\left\{\begin{array}{cc}E_{s} k_{E s, \theta} \varepsilon_{s}, & \text { for } \varepsilon_{s}<\varepsilon_{y d, \theta} \\ f_{y} k_{s, \theta}, & \text { for } \varepsilon_{s} \geq \varepsilon_{y d, \theta}\end{array}\right.$

where $f_{y}$ is the steel tensile strength of the passive reinforcement at room temperature, $E_{s}$ is the modulus of elasticity of the steel at room temperature, $k_{s, \theta}$ and $k_{E s, \theta}$ are the factors of reduction of tensile strength and the modulus of elasticity of steel at high temperatures, 
a

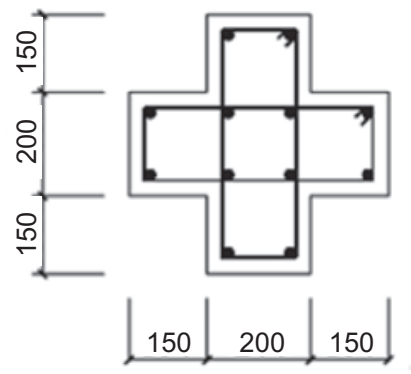

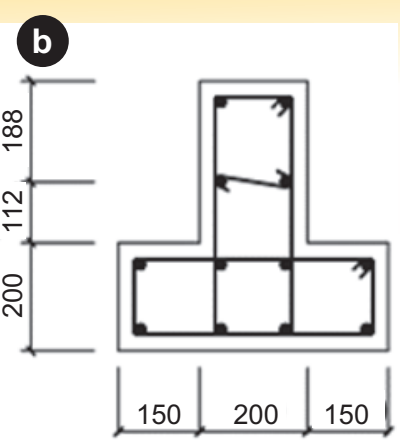

Figure 5

Size of columns (in millimeters) with (a) "+" and (b) "T" sections [2]

respectively, indicated in ABNT NBR 15200:2012 [36], $\varepsilon_{s}$ is the specific strain of the reinforcement and $\sigma_{s}$ is the normal stress in the steel at high temperatures.

f) calculation of the design strength (axial load and bending moments)

With the stresses determined at each Gauss point, it can be calculated the cross-section design strength to axial load $\left(N_{R d}\right)$ and the bending moments $\left(M_{x, R d}\right.$ and $\left.M_{y, R d}\right)$ using a Gaussian quadrature integration, according to Equations (19), (20) and (21):

$N_{R d}=\sum_{e=1}^{n e l e m} \sum_{p=1}^{n p g} \sigma_{e, p}|J| w$

$M_{x, R d}=\sum_{e=1}^{n e l e m} \sum_{p=1}^{n p g} \sigma_{e, p}\left(y_{e, p}-y_{g}\right)|J| w$

$M_{y, R d}=-\sum_{e=1}^{n e l e m} \sum_{p=1}^{n p g} \sigma_{e, p}\left(x_{e, p}-x_{g}\right)|J| w$

where $\sigma_{e, p}$ is the stress at a Gauss point $(p)$ of a given element $(e)$ with coordinates $\left(x_{e, p}, y_{e, p}\right)$ and the other parameters have already been defined.

\subsection{Computational implementation}

The computer program developed in this study, called Pisafo, was implemented in the Delphi development environment, using the Object Pascal language, in compatibility with the algorithms of the mesh generator [34] and Thersys [7].
Based on the finite element mesh and the temperatures obtained in the thermal analysis, Pisafo integrates the stresses in the reinforced concrete cross-section in order to obtain the design strength, considering the variables $\delta$ and $\beta$. Thus, an algorithm that allows to vary $\delta$ and $\beta$ has been implemented in order to obtain the interaction diagrams:

- $M_{y} \times M_{x}$, for a set value of $N$;

- $M_{x} \times N$, for a set value of $M_{y}$; and

- $M_{y} \times N$, for a set value of $M_{x}$.

\section{Results and discussion}

Examples of application were made with the objective of validating the program Pisafo. The results of the maximum axial load supported by columns of different sections were compared with those presented in the technical literature, obtained in experiments. The results of the maximum bending moment supported by beams, in order to validate the calculations of the bending moments, and the $M_{y} \times M_{x}$ interaction diagrams were also compared with the technical literature, obtained with the use of recognized programs.

\subsection{Experiments of $\mathrm{Xu}$ and $\mathrm{Wu}[2]$}

Two columns with "+" and "T" section were analyzed, following the same conditions of the experiments performed by $\mathrm{Xu}$ and $\mathrm{Wu}$ [2]. The tests consisted of applying a centrally compression axial load to the column, which remained constant during exposure to fire, until rupture of the structural element.

The standard fire curve of ISO 834-1:1999 [21] was used for fire simulation. The columns had 12 longitudinal bars with $16 \mathrm{~mm}$ diameter and a yield strength of $418 \mathrm{MPa}$. In Pisafo, concrete with silica aggregate, moisture content of $2 \%$ and concrete cover of 30 $\mathrm{mm}$ were considered, highlighting that the authors [2] did not specify the concrete cover used. The ultimate strength experiments of the columns were performed between 150 and 180 days after concreting, and they were calculated to have an average compressive strength of approximately $25 \mathrm{MPa}$.

With respect to the boundary conditions, the columns under analysis have all their faces exposed to fire. The dimensions of the columns studied are shown in Figure 5.

a) "+" section

The column had a cubic strength $f_{c u}$ of $37.6 \mathrm{MPa}$ after 150 days of concreting, equivalent to a cylindrical strength $f_{c k}$ [38] of $30.38 \mathrm{MPa}$.
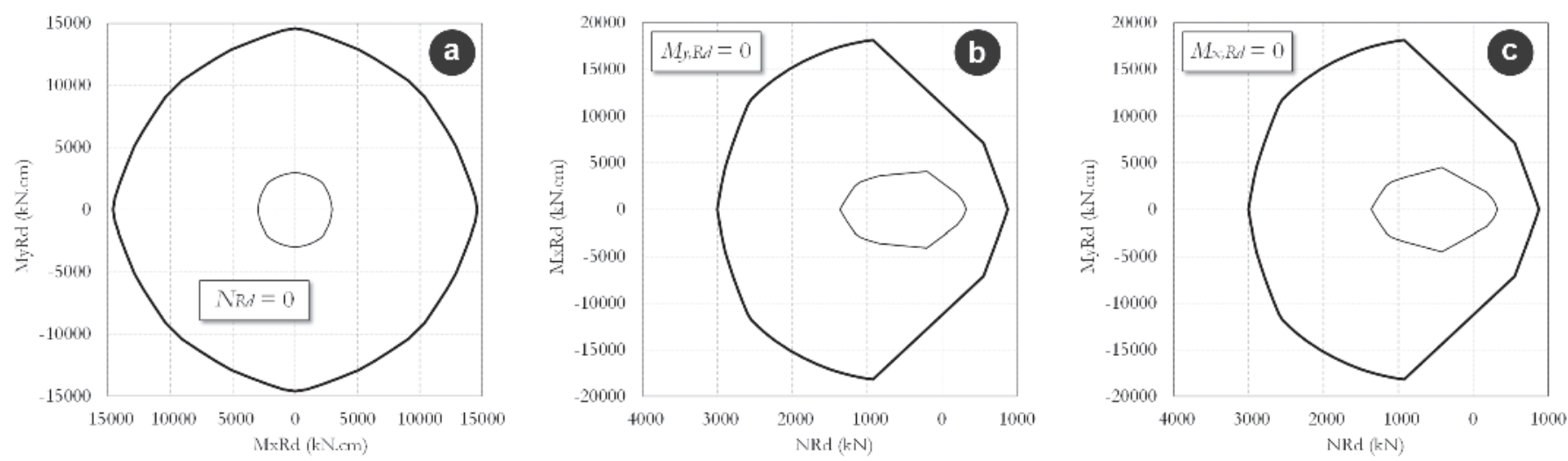

Figure 6

Interaction diagrams of bending moments and axial load using diagrams proposed by ABNT NBR 15200:2012: (a) $M_{y, R d} \times M_{x, R d^{\prime}}$ (b) $M_{x, R d} \times N_{R d}$ and (c) $M_{y, R d} \times N_{R d}$ (room temperature: thick line; 245 minutes of fire: thin line) 
In the experiment, the column was subjected to a compression axial load of $1480 \mathrm{kN}$. It supported 245 minutes until it collapse.

With Pisafo, it was possible to obtain the largest compression axial load supported by the cross section of the column, besides the in-



\section{Figure 7}

Position of the thermocouples in the " + " section (size in millimeters) [2]


Figure 8

Temperatures obtained at "+" section teraction diagram of bending moments and axial load for the room temperature and in fire situation (Figure 6).

In order to obtain cross-section temperatures during the test, the authors installed thermocouples at four points in the section, as shown in Figure 7. Thus, it was possible to compare the temperatures calculated by Pisafo with the temperatures measured and calculated by $\mathrm{Xu}$ and $\mathrm{Wu}$ [2], according to Figure 8 . There was a good agreement between the experimental results and those obtained by Pisafo.

\section{b) "T" section}

The column showed a cubic strength $f_{c u}$ of $34.8 \mathrm{MPa}$ after 150 days of concreting, corresponding to a cylindrical strength $f_{c k}$ [38] of $28.43 \mathrm{MPa}$. In the experiment, the column was subjected to a compression axial load of $1902 \mathrm{kN}$. It supported 148 minutes of fire until collapse.

Table 2 lists the results obtained by Pisafo using the diagrams proposed in ABNT NBR 6118:2014 [35] modified for high temperatures and the diagrams proposed in ABNT NBR 15200:2012 [36], with their respective errors in relation to experimental results obtained by $\mathrm{Xu}$ and $\mathrm{Wu}$ [2]. In the numerical analyses, the seeds for mesh generation were $20 \mathrm{~mm}$ for the concrete elements and $8 \mathrm{~mm}$ for the steel elements.

The use of the diagrams proposed in ABNT NBR 6118:2014 modified for high temperatures tends to overestimate the strength capacity of the structural element, while the use of the diagrams proposed in ABNT NBR 15200:2012 leads to results closer to those
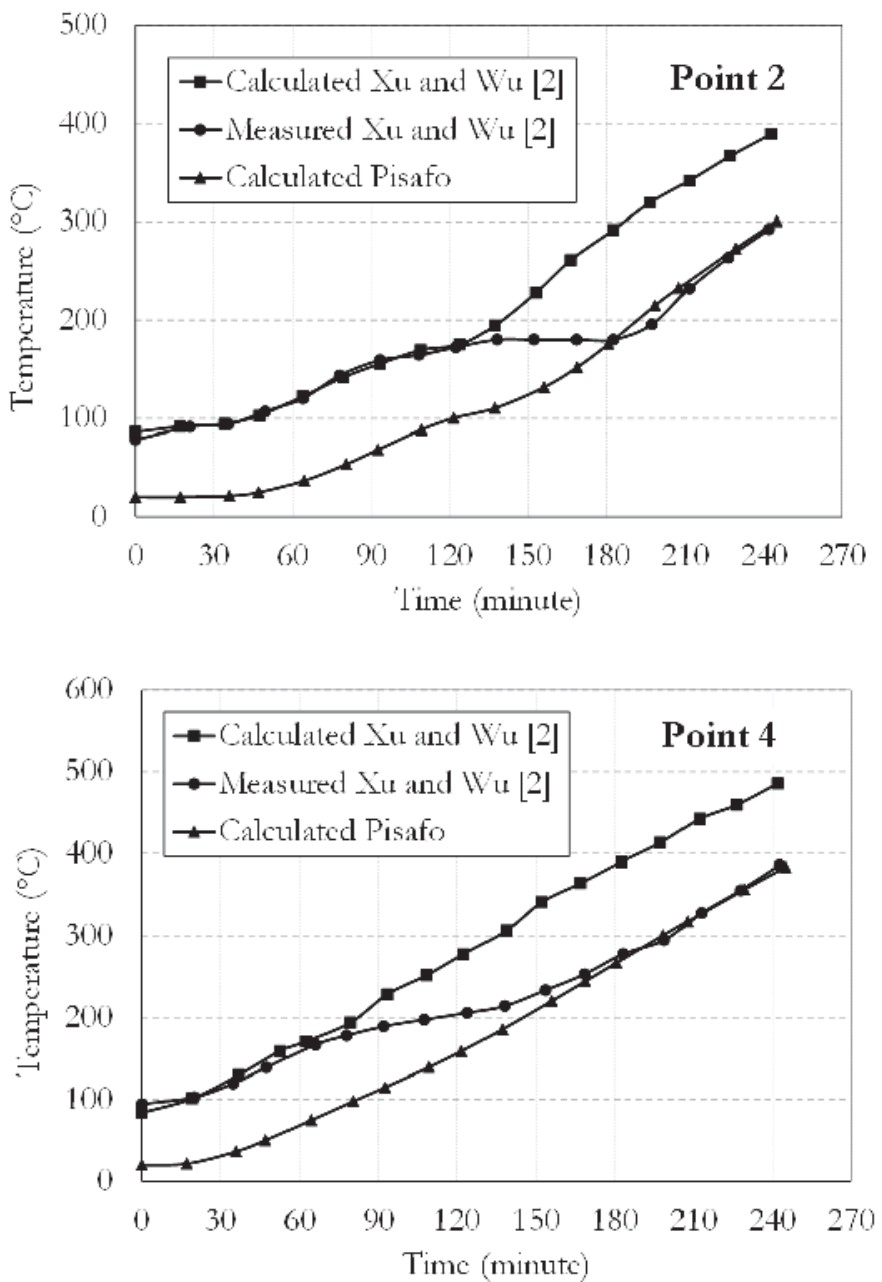
Table 2

Axial load strength ( $\mathrm{kN}$ ) of "+" and "T" sections

\begin{tabular}{|c|c|c|c|c|c|}
\hline \multirow{2}{*}{ Section } & \multirow{2}{*}{ Xu and Wu [2] } & \multicolumn{2}{|c|}{ Diagrams of NBR 6118 [35] } & \multicolumn{2}{|c|}{ Diagrams of NBR 15200 [36] } \\
\hline & & Pisafo & Error & Pisafo & Error \\
\hline+ & -1480 & -1721.77 & $16.3 \%$ & -1363.45 & $-7.9 \%$ \\
\hline $\mathrm{T}$ & -1902 & -2444.04 & $28.5 \%$ & -1992.39 & $4.8 \%$ \\
\hline
\end{tabular}
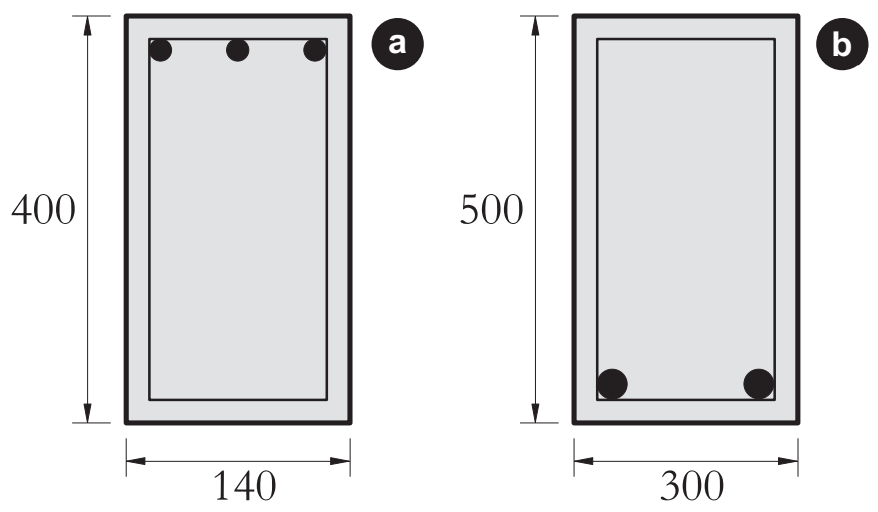

\section{Figure 9}

Sizes of the beams (in millimeters) with

(a) negative and (b) positive reinforcement

obtained in experiments. In general, the results obtained by Pisafo proved to be satisfactory when compared with the experimental results of $\mathrm{Xu}$ and $\mathrm{Wu}$ [2].

\subsection{Super TempCalc}

The experiments performed by $\mathrm{Xu}$ and $\mathrm{Wu}$ [2] restricted any rotation and horizontal displacement at the ends of the columns, allowing only vertical displacement. With this, it became necessary to validate the calculation of the bending moment strength by means of the analysis of beams.

For this, the Swedish computer program Super TempCalc, developed by Fire Safety Design [39] was used. The analyses considered the standard fire curve of ISO 834-1:1999 [21], concrete with silica aggregate, with a compressive strength of $25 \mathrm{MPa}$ and a moisture content of $1.5 \%$. The reinforcement bars were of steel with yield strength of $500 \mathrm{MPa}$.

It was considered that three faces of the beam (lateral and inferior) were exposed to the fire, being the superior face defined as adiabatic. The sizes of the beams with positive reinforcement and negative reinforcement are shown in Figure 9.

\section{a) beam with negative reinforcement}

The reinforced beam considered had 3 bars of $10 \mathrm{~mm}$ and with concrete cover of $25 \mathrm{~mm}$. The fire time for thermal analysis was 60 minutes. As occurred for columns, a smaller size of the elements in the concrete and steel mesh results in a higher strength of the structure. However, with that consideration, the time spent for thermal analysis also becomes longer.

Table 3 lists the results obtained by Pisafo using the diagrams proposed in ABNT NBR 6118:2014 [35] modified for high temperatures and the diagrams proposed by ABNT NBR 15200:2012 [36], with the respective errors in relation to the result obtained by Super TempCalc [39]. In this table, the seed used for the mesh generator in case A: 15 $\mathrm{mm}$ for concrete elements and $6 \mathrm{~mm}$ for steel elements, and in case B: $10 \mathrm{~mm}$ for concrete elements and $4 \mathrm{~mm}$ for steel elements.

b) beam with positive reinforcement

For the case of positive reinforcement, the reinforced beam adopted had 2 bars of $25 \mathrm{~mm}$ and concrete cover of $40 \mathrm{~mm}$. The fire time for the thermal analysis was 120 minutes.

Table 4 presents the results obtained by Pisafo in comparison to the result obtained by Super TempCalc, with the same considerations of the meshes and of the stress-strain diagrams of the materials made in the previous subitem.

In the case of cross-sections subjected to bending, the results obtained by Pisafo were accurate for situation of negative bending moment and relatively conservative for situation of positive bending moment. In this case, the diagrams used $[35,36]$ had less interference in the results obtained.

\section{3 $M_{y} \times M_{x}$ interaction diagram at room temperature}

Also for validation of Pisafo, the comparison was made between a $M_{y} \times M_{x}$ interaction diagram generated by Pisafo and the same diagram obtained, at room temperature, by the web application developed at USP (http://www.Imc.ep.usp.br/pesquisas/TecEdu/). The cross-section of reinforced concrete considered in this validation has $20 \times 20 \mathrm{~cm}^{2}$, consisting of concrete with $f_{c k}$ of $25 \mathrm{MPa}$ and 4 steel bars of CA50 with a diameter of $10 \mathrm{~mm}$ and with $25 \mathrm{~mm}$ of concrete cover. The fire analysis used the standard fire curve

\section{Table 3}

Bending moment strength $(\mathrm{kN} . \mathrm{cm})$ of the beam with negative reinforcement

\begin{tabular}{|c|c|c|c|c|c|}
\hline \multirow{2}{*}{$\begin{array}{c}\text { Super TempCalc } \\
{[39]}\end{array}$} & \multirow{2}{*}{ Case } & \multicolumn{2}{|c|}{ Diagrams of NBR 6118 [35] } & \multicolumn{2}{|c|}{ Diagrams of NBR 15200 [36] } \\
\hline & & Pisafo & Error & Pisafo & Error \\
\hline \multirow{2}{*}{3742.12} & $A$ & 3722.70 & $-0.52 \%$ & 3618.61 & $-3.30 \%$ \\
\hline & B & 3726.14 & $-0.43 \%$ & 3624.67 & $-3.14 \%$ \\
\hline
\end{tabular}

\section{Table 4}

Bending moment strength $(\mathrm{kN} . \mathrm{cm})$ of the beam with positive reinforcement

\begin{tabular}{|c|c|c|c|c|c|}
\hline \multirow{2}{*}{$\begin{array}{c}\text { Super TempCalc } \\
{[39]}\end{array}$} & \multirow{2}{*}{ Case } & \multicolumn{2}{|c|}{ Diagrams of NBR 6118 [35] } & \multicolumn{2}{|c|}{ Diagrams of NBR 15200 [36] } \\
\hline & & Pisafo & Error & Pisafo & Error \\
\hline \multirow{2}{*}{13826.66} & $A$ & 11888.87 & $-14.0 \%$ & 11773.64 & $-14.8 \%$ \\
\hline & B & 11928.78 & $-13.7 \%$ & 11812.43 & $-14.6 \%$ \\
\hline
\end{tabular}


of ISO 834-1:1999 [21], $0 \%$ moisture content for concrete and all faces exposed to fire (Figure 10). The cross section was also subjected to an axial load of $420 \mathrm{kN}$.

For validation of calculations of the column in fire situation, a TRRF of 0.1 minute was set. In this way, the section does not reach a high temperature and, with this, there is no reduction in mechanical properties. When considering factors for actions and strength in fire situation identical to those used at room temperature, the results of the interaction diagram in fire situation shall be the same as the results at room temperature. It was used as seed for the mesh generator: $15 \mathrm{~mm}$ for the concrete elements and $6 \mathrm{~mm}$ for the steel elements. The $M_{y} \times M_{x}$ interaction diagram of the column obtained by the USP web application (at room temperature) and by Pisafo (at room temperature and in fire situation) are illustrated in Figure 11. As expected, it is observed that the interaction diagrams at room temperature and in fire situation obtained by Pisafo are coincident and very close to the interaction diagram obtained by the USP web application, which allows to validate the algorithm implemented in Pisafo.

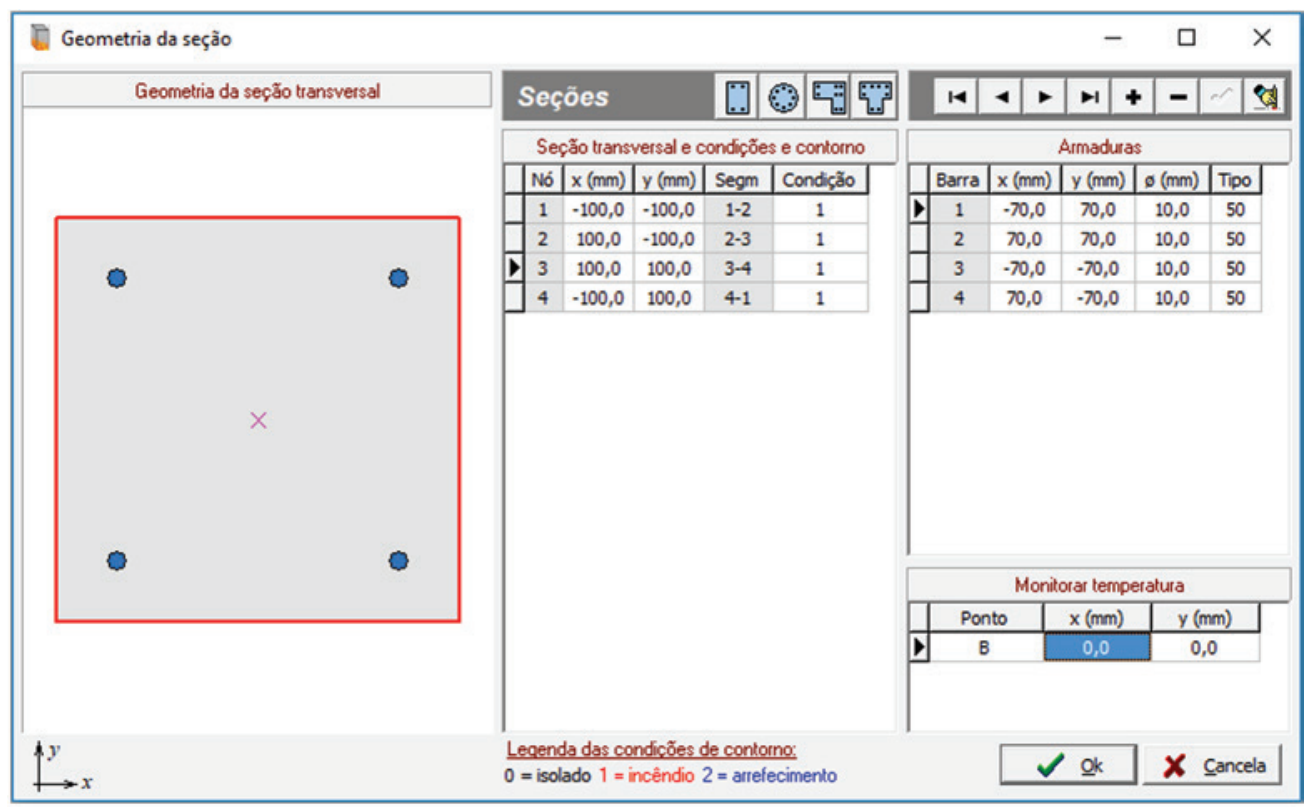

\section{Figure 10}

Modeling the cross section of the column in Pisafo
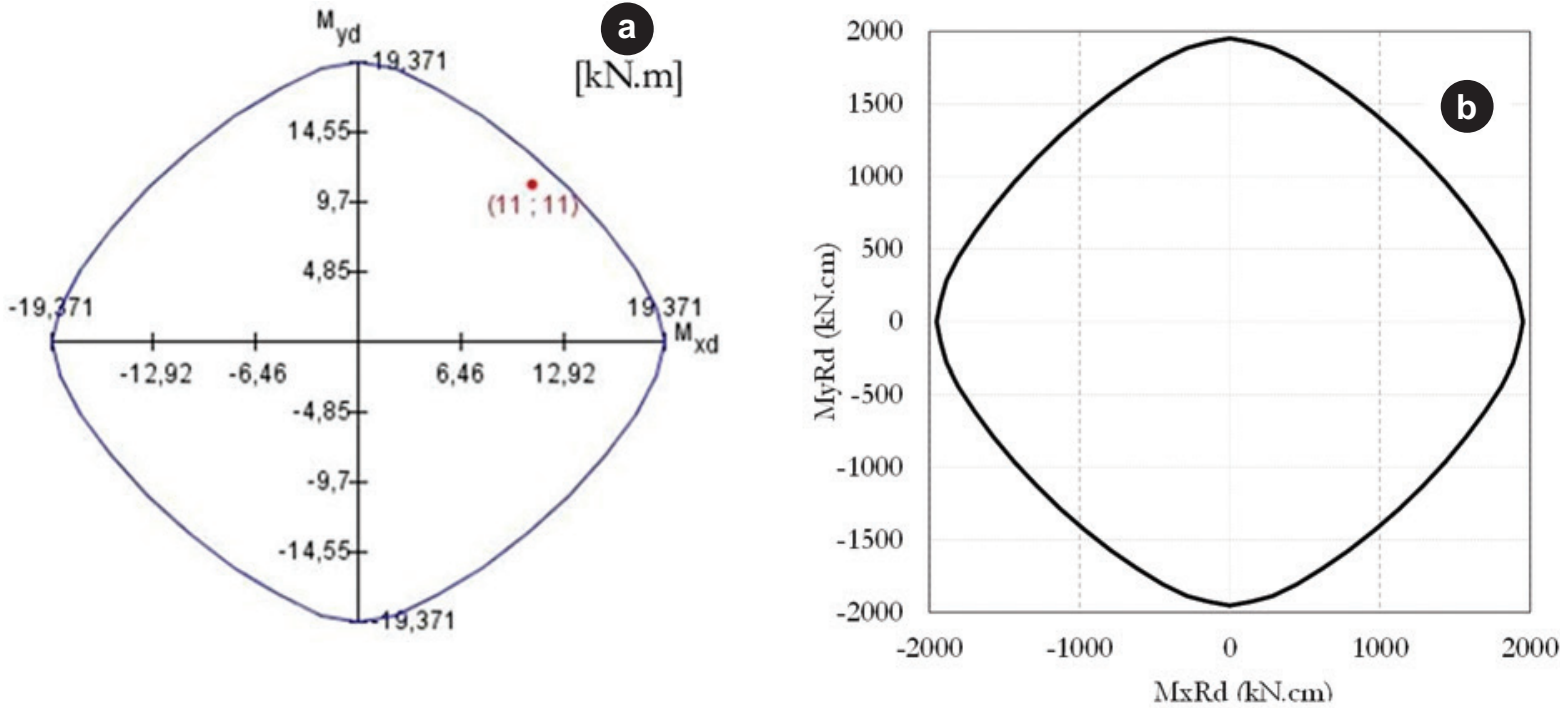

\section{Figure 11}

$M_{y} \times M_{x}$ interaction diagrams obtained by (a) web application of USP and (b) Pisafo - at room temperature and in fire (the curves are overlapped because they are identical) 


\section{Table 5}

Bending moment strength $M_{x}$ and $M_{y}(k N . c m)$ obtained by the application of USP and by Pisafo (using the diagrams proposed in ABNT NBR 61 18:2014 [35])

\begin{tabular}{cccc}
\hline $\begin{array}{c}\text { Design } \\
\text { strength }\end{array}$ & $\begin{array}{c}\text { Application } \\
\text { of USP }\end{array}$ & Pisafo & Error \\
\hline$M_{x}$ & 1937.1 & 1952.62 & $0.8 \%$ \\
$M_{y}$ & 1937.1 & 1952.65 & $0.8 \%$ \\
\hline
\end{tabular}

Table 5 lists the numerical results of the bending moment strengths obtained by Pisafo using the diagrams proposed in ABNT NBR 6118:2014 [35], in comparison to the results obtained by the USP web application, showing that the results are very close.

\section{4 $M_{y} \times M_{x}$ interaction diagram in fire situation}

In order to evaluate the $M_{y} \times M_{x}$ interaction diagram in fire situation, a comparison was made between the numerical analysis developed by Cherem and Silva [16] and the results obtained by Pisafo for the same problem.

Cherem and Silva [16] analyzed a concrete column of $30 \times 30$ $\mathrm{cm}^{2}$, using a concrete with $f_{c k}$ of $30 \mathrm{MPa}$ and 8 CA50 steel bars with a diameter of $10 \mathrm{~mm}$ and with a $30 \mathrm{~mm}$ of concrete cover. The fire analysis considered the standard fire curve of ISO 834-1:1999 [21] with a fire time of 90 minutes, a moisture content of $4 \%$ for concrete and all faces exposed to fire (Figure 12). The cross section was also subjected to a compression axial load of $761.22 \mathrm{kN}$, corresponding to approximately $40 \%$ of the room temperaturecentered compressive strength, according to the authors. For the Pisafo mesh generation, the seed used had $15 \mathrm{~mm}$ for the concrete elements and $6 \mathrm{~mm}$ for the steel elements.

Due to the double symmetry of the section, Figure 13 illustrates a quarter of the $M_{y} \times M_{x}$ interaction diagram obtained by Cherem and

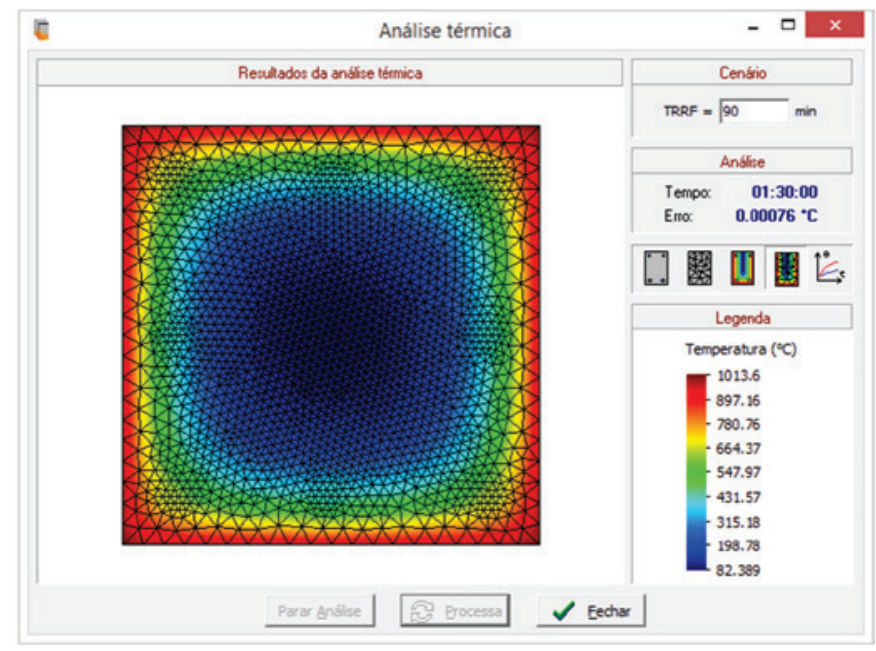

\section{Figure 12}

Results of the thermal analysis obtained by Pisafo for the column under study [16]

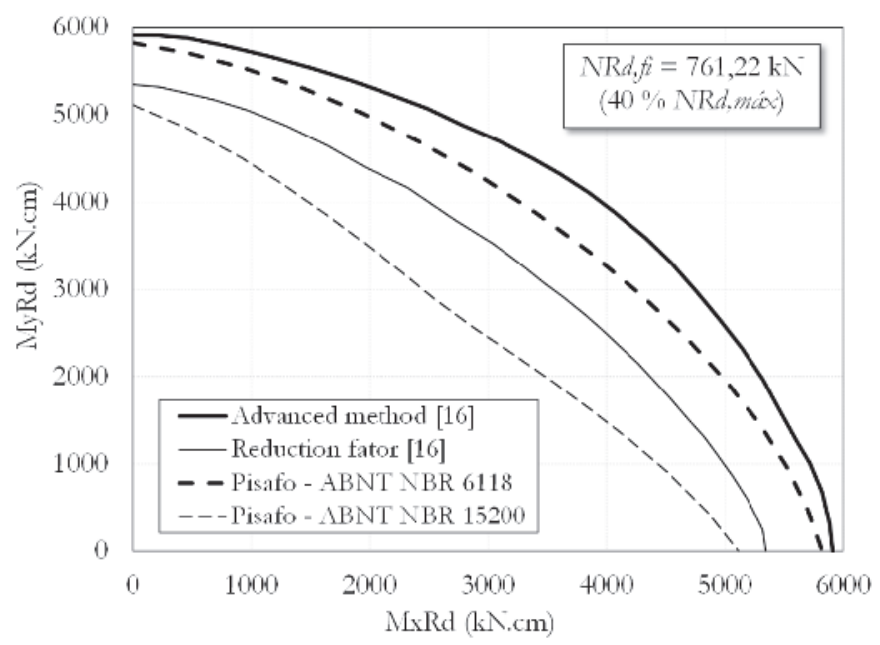

Figure 13

Comparison of the $\mathrm{M}_{\mathrm{y}} \times \mathrm{M}_{\mathrm{x}}$ interaction diagram obtained by Pisafo and Cherem and Silva [16], using the Advanced method and the Reduction factor (proposed by these authors)

Silva [16] and by Pisafo. The "Advanced method" [16] consists of obtaining the maximum strength of the section using the stressstrain curves proposed in ABNT NBR 15200:2012 by means of an algorithm that varies the strain in the center of gravity of the section and the curvatures around of the $x$ and $y$ axes, without limiting the maximum strain in the materials [36]. The "Reduction factor" [16] is an analytical method proposed by the authors, which consists of adjusting the $M_{y} \times M_{x}$ interaction diagram at room temperature for a reasonable approximation in a fire situation, without the need for thermal analysis.

It is observed in Figure 13 that, since Pisafo obtains the interaction diagram based on the strain profile $[17,35,36]$, the interaction diagram obtained using the stress-strain diagrams of ABNT NBR 6118:2014 adapted for high temperatures is more conservative than the "Advanced method" [16], but still presenting an excellent adjustment (between $-1.5 \%$ and $-10.3 \%$ ). When using the stress-strain diagrams of ABNT NBR 15200:2012, the interaction diagram obtained by Pisafo is even more conservative, as already observed in item 3.1, but close to the "Reduction factor" method [16], considered as reasonable by the authors.

\section{Conclusions}

In this study, a computational algorithm, called Pisafo, was developed to verify any sections of reinforced concrete subjected to unsymmetrical bending at room temperature and in fire situation. The algorithm was implemented in the Delphi development environment, whose programming language is Object Pascal. It was used the EasyMesh mesh generator, developed by MIT, and the Thersys thermal analysis algorithm, developed by Ribeiro [7]. The mechanical analysis consists of a stress integration algorithm, based on the strain profile of the cross section, given by the strain domains prescribed in ABNT NBR 6118:2014. 
Pisafo allows the use of any fire curve in thermal analysis as well as various cross-sectional shapes by having a finite element mesh generator incorporated into the program. As results, Pisafo allows the elaboration of the interaction diagrams of the cross section: $M_{y}$ $\times M_{x}, M_{y} \times N$ and $M_{x} \times N$.

For validation of the implemented algorithm, the axial load strength of "+" and "T" section columns obtained by Pisafo were compared with values presented in the technical literature, obtained in experiments. In addition, the bending moment strength of beams, as well as the $M_{y} \times M_{x}$ interaction diagrams, were also compared with results found in the technical literature, obtained with the use of recognized programs.

The results obtained by Pisafo in the analysis of columns subjected to the centered compression, when compared with the experimental results presented by $\mathrm{Xu}$ and $\mathrm{Wu}$ [2], were greater when using the diagrams proposed by ABNT NBR 6118:2014 modified for fire situation, reaching a difference of up to $28.5 \%$. When using the diagrams proposed by ABNT NBR 15200:2012, the strength values obtained by Pisafo were closer to the experimental results, with differences from $-7.88 \%$ to $5.06 \%$, depending on the type of cross section.

When comparing the results obtained by Pisafo for bending moment strength with those obtained by the web application developed at USP and by the software Super TempCalc, the errors are smaller. In relation to Super TempCalc, the differences reach $-14.8 \%$ when using the diagrams proposed by ABNT NBR 6118:2014 and ABNT NBR 15200:2012. Regarding the USP web application, for analysis at room temperature, the differences obtained using the diagrams proposed by ABNT NBR 6118:2014 are negligible, of the order of $0.80 \%$. However, the comparison of the interaction diagrams in fire situation obtained by Pisafo and in the work of Cherem and Silva [16], also with the diagrams proposed by ABNT NBR 6118:2014, lead to larger differences of the order of $-1.5 \%$ to $-10.3 \%$.

It is believed that some factors contributed to this larger difference from the experimental results of $\mathrm{Xu}$ and $\mathrm{Wu}$ [2]. The first is because the real thermal properties of the concrete used in the tests are not exactly the same as those used by Pisafo, which uses values provided in the standards. Another factor that also contributes to this difference is the fact that the articles do not specify all the conditions of the test, such as the lack of data on the concrete cover or the moisture content of the concrete. In addition, it is emphasized the non-consideration of spalling in the computational analysis, which was also omitted by $\mathrm{Xu}$ and $\mathrm{Wu}$ [2] in the experimental results.

\section{Acknowledgements}

This study was financed in part by the Coordenação de Aperfeiçoamento de Pessoal de Nível Superior - Brasil (CAPES) - Finance Code 001. The authors also thank the Department of Civil Engineering of UFV for the infrastructure provided for the development of this work.

\section{References}

[1] BRUSHLINSKY, N. N.; AHRENS, M.; SOKOLOV, S. V.;
WAGNER, P. World Fire Statistics. Center of Fire Statistics of International Association of Fire and Rescue Service, report n. 21, 2016

[2] $\mathrm{XU}, \mathrm{Y}$;; WU, B. Fire resistance of reinforced concrete columns with L-, T- and +-shaped cross-sections. Fire Safety Journal, v.44, p.869-880, 2009. https://doi.org/10.1016/j.firesaf.2009.04.002

[3] FRANSSEN, J. M.; DOTREPPE, J. C. Fire tests and calculation methods for circular concrete columns. Fire Technology, v. 39, p. 89-97, 2003.

[4] LIE, T. T.; WOOLERTON, J. L. Fire resistance of reinforced concrete columns - Test results. National Research Council Canada, Internal Report, n 569. 1988.

[5] CHEN, Y.; CHANG, Y.; YAO, G. C.; SHEU, M. Experimental research on post-fire behaviour of reinforced concrete columns. Fire Safety Journal, v. 44, p. 741-748, 2009.

https://doi.org/10.1016/j.firesaf.2009.02.004

[6] FAKURY, R. H.; LAS CASAS, E. B.; FIGUEIREDO Jr, F. P.; ABREU, L. M. P. Design of semi-continuous composite steel-concrete beams at the fire limit state. Journal of Constructional Steel Research, v. 61, n. 8, p. 1094-1107, 2005. https://doi.org/10.1016/j.jcsr.2005.02.003

[7] RIBEIRO, J. C. L. Simulação via método dos elementos finitos da distribuição tridimensional de temperatura em estruturas em situação de incêndio, Belo Horizonte, 2004, Dissertação de Mestrado - Escola de Engenharia, Universidade Federal de Minas Gerais.

[8] VILA REAL, P. M. M. Modelação por elementos finitos do comportamento térmico e termo-elástico de sólidos sujeitos a elevados gradientes térmicos, Porto (Portugal), 1988, Dissertação de Mestrado - Faculdade de Engenharia, Universidade do Porto.

[9] RIBEIRO, J. C. L.; FAKURY, R. H.; LAS CASAS, E. B. Desenvolvimento de um sistema via método dos elementos finitos para simulação do comportamento de elementos estruturais de aço e mistos em situação de incêndio. Revista Sul-Americana de Engenhara Estrutural, v. 8, n. 3, p. 2033, 2011.

[10] LIE, T. T.; CELIKKOL, B. Method to calculate the fire resistance of circular reinforced concrete columns. ACI Materials Journal, v. 88, n. 1, p. 84-91, 1991.

[11] DOTREPPE, J. C.; FRANSSEN, J. M.; VANDERZEYPEN, $Y$. Calculation method for design of reinforced concrete columns under fire conditions. ACI Structural Journal, vol. 96, n. 1, p. 9-18, 1999.

[12] SOARES, E. M. P.; SILVA, N. A. Verificação de peças usuais de concreto armado em situação de incêndio. In: XXXI Jornadas Sulamericanas de Engeniería Estructural, 2004, Mendoza.

[13] RODRIGUES, M. P. P.; SILVA, N. A. Flexão normal composta em seções retangulares de concreto armado em situação de incêndio. In: $51^{\circ}$ Congresso Brasileiro do Concreto, 2009, Curitiba. Anais do 51 Congresso Brasileiro do Concreto. São Paulo: Ibracon, v. 51, 2009.

[14] LIE, T. T.; IRWIN, R. J. Method to calculate the fire resistence of reinforced concrete columns wih rectangular cross section. ACI Structural Journal, v. 90, n. 1, p 52-60, 1993. 
[15] ALBUQUERQUE, G. B. M. L.; SILVA, V. P. Dimensionamento de vigas de concreto armado em situação de incêndio por meio gráfico. Revista IBRACON de Estruturas e Materiais, v.6, n.4, p.513-536, 2013.

[16] CHEREM, M.; SILVA, V. P. Determination of the ULS, for columns with small dimensions, undex biaxial bending and symmetrical fire conditions. IBRACON Structures and Materials Journal, v. 10, n. 2, p. 451-476, 2017. http://dx.doi. org/10.1590/S1983-41952017000200009

[17] MOREIRA, A. M. M.; SILVA, N. A.; SILVA, R. M. Verificação de seções retangulares de concreto armado submetidas à flexão oblíqua composta em situação de incêndio. In: Iberian Latin American Congress on Computational Methods in Engineering, 34 , Pirenópolis, 2013, Anais, 2013, p.1-19.

[18] SILVA, V. P. Projeto de estruturas de concreto em situação de incêndio, São Paulo: Blucher, 2ed, 2016, 237 p.

[19] BARNETT, C. R. BFD curve: a new empirical model for fire compartment temperatures. Fire Safety Journal, v.37, 2002; p.437-463. https://doi.org/10.1016/S0379-7112(02)00006-1

[20] EUROPEAN COMMITTEE FOR STANDARTIZATION. Eurocode 1: Actions in structures: part 1-2 General actions Actions on structures exposed to fire. - EN1991-1-2:2002, Bruxelas, Bélgica, 2002.

[21] INTERNATIONAL ORGANIZATION FOR STANDARDIZATION. ISO 834: fire-resistance tests: elements of building construction - part 1.1: general requirements for fire resistance testing. - ISO834-1:1999, Geneva, 1999.

[22] ASSOCIAÇÃO BRASILEIRA DE NORMAS TÉCNICAS. EXigências de resistência ao fogo de elementos construtivos de edificações - Procedimento. - NBR 14432, Rio de Janeiro, 2001.

[23] BUCHANAN, A. H. Structural design for fire safety, New York: Wiley, 2001, $421 \mathrm{p}$.

[24] BATTISTA, R. C.; BATISTA, E. M.; CARVALHO, E. M. L. Reabilitação estrutural do prédio do aeroporto Santos Dumont após danos causados por incêndio. Rev. Int. de Desastres Naturales, Accidentes e Infraestructura Civil, Puerto Rico, v.1, n.1, 2001; p.51-60.

[25] DHIR, R. K.; CHANA, P.; CALISKAN, S.; LAVINGIA, R. Concrete for fire engineering, Watford: IHS BRE Press, 2008, $322 \mathrm{p}$.

[26] KHOURY, G. A. Effect of fire on concrete and concrete structures. Progress in Structural Engineering and Materials, v.2, n.4, 2000; p.429-447. http://dx.doi.org/10.1002/pse.51

[27] LANDI, F. R. Ação do incêndio sobre as estruturas de concreto armado, São Paulo, 1986, Boletim Técnico BT / PCC - 86/001, Escola Politécnica da Universidade de São Paulo.

[28] KALIFA, P.; MENNETEAU, F. D.; QUENARD, D. Spalling and Pore Pressure in HPC at High Temperatures. Cement and Concrete Research, n. 30. Elsevier Science Ltd. Amsterdam, 2000.

[29] EUROPEAN COMMITTEE FOR STANDARTIZATION. Eurocode 2: Design of concrete structures: Part 1-2: General rules - Structural fire design. - EN1992-1-2:2004, Bruxelas, Bélgica, 2004.

[30] PURKISS, J. A.; LI, L. Y. Fire safety engineering design of structures, Boca Raton-FL: CRC Press, 3ed, 2014.
[31] KODUR, V. R.; SULTAN, M. A. Structural behaviour of high strength concrete columns exposed to fire. In: International Symposium on High Performance and Reactive Powder Concrete, p. 217-232, 1998.

[32] DEENY, S.; STRATFORD, T.; DHAKAL, R. P.; MOSS, P. J.; BUCHANAN, A. H. Spalling of concrete: implications for structural performance in fire. In: Australasian Conferences on the Mechanics of Structures and Materials, $20^{\circ}$, Toowoomba (University of Southern Queensland), p.1-5, 2008.

[33] NICENO, B. EasyMesh: A two-dimensional quality mesh generator. MIT \& Consortium for International Development of the University of Trieste.

http://web.mit.edu/easymesh_v1.4/www/easymesh.html. Acesso em: 15/mar/2015.

[34] BITENCOURT, O. S.; RIBEIRO, J. C. L.; ALVARENGA, R. C.S. Desenvolvimento de gerador de malhas bidimensional, Viçosa, 2016, Relatório de pesquisa, Departamento de Engenharia Civil, Universidade Federal de Viçosa.

[35] ASSOCIAÇÃO BRASILEIRA DE NORMAS TÉCNICAS. Projeto de estruturas de concreto - Procedimento. - NBR 6118, Rio de Janeiro, 2014.

[36] ASSOCIAÇÃO BRASILEIRA DE NORMAS TÉCNICAS. Projeto de estruturas de concreto em situação de incêndio Procedimento. - NBR 15200, Rio de Janeiro, 2012.

[37] CASTRO, G. G. S. Um método geral de cálculo para verificação de estruturas de concreto em situação de incêndio, Belo Horizonte, 2005, Dissertação de Mestrado - Escola de Engenharia, Universidade Federal de Minas Gerais.

[38] EUROPEAN COMMITTEE FOR STANDARTIZATION. Eurocode 2: Design of concrete structures: Part 1-1: General rules and rules for buildings. - EN1992-1-1:2004, Bruxelas, Bélgica, 2004.

[39] Fire Safety Design - FSD. TCD 5.0 User's manual. Lund: Fire Safety Design AB, p.129, 2007. 